\title{
PROČ NEBYLO ČESKOSLOVENSKO REPUBLIKOU HNED OD 28. ŘÍJNA 1918?*
}

\author{
JAN KUKLÍK
}

\begin{abstract}
Why Czechoslovakia was not proclaimed as a republic directly on 28 October 1918?
The study deals with the problems connected with the republican form of newly established Czechoslovak state. The Czechoslovak state was solemnly proclaimed in Prague on 28 October 1918 by the Czechoslovak National Committee, which issued the first Czechoslovak Act on the Establishment of the Independent Czechoslovak State, which was published as Act No. 11 of a new Czechoslovak Collection of Laws. A decision on a republican form of government was postponed until negotiations with the Czechoslovak politicians in exile took place in Switzerland. The delegation of the Provisional Government, headed by Edvard Beneš, reached an agreement with the representatives of the National Committee, headed by Kramář, on an independent Czechoslovakia and on its republican form. The republic was finally proclaimed by the Provisional Constitution of 13 November 1918. The delay was caused not only by the revolutionary circumstances connected with the end of WWI, but also because the idea of republic was connected with far reaching democratic political, economic and social reforms and the political leaders of the Czech nation had to accept this.
\end{abstract}

Keywords: establishment of Czechoslovakia 1918; Czechoslovak constitutional development; Provisional Constitution 1918; republican form of government

Klíčová slova: vznik Československa 1918; recepční zákon; prozatímní ústava; republikánská forma státu

DOI: $10.14712 / 23366478.2018 .19$

Vznikající československá státnost je úzce spojena především s tzv. recepčním zákonem a prozatímní ústavou. Jednou z problematických otázek vzniku Československa je rozhodnutí o jeho republikánské formě. Je dokonce možné říci, že Československo se stalo republikou nejprve fakticky, prohlašováním na náměstích, a teprve posléze i ústavně. A i to ústavní zakotvení nebylo př́liš povedené.

Vznik československého státu byl vnitropoliticky realizován především Národním výborem, který původně vznikl jako reprezentativní orgán domácí politiky již v roce 1916. V průběhu let 1917-18 dospěly postupně české politické strany $\mathrm{k}$ přesvědčení,

* Tento článek byl vypracován v rámci programu PROGRES Q04. Autor je profesorem katedry právních dějin Právnické fakulty Univerzity Karlovy. 
že s rakouskou vládou již nemá cenu dále jednat a že je třeba budoucnost českých zemí hledat mimo dosavadní rámec monarchie. V červenci 1918 byl tedy Národní výbor zásadně reorganizován, aby na základě výsledků posledních voleb do říšské rady, konaných roku 1911, odrážel předpokládanou sílu českých politických stran. Měl celkem 38 členů. Jeho předsedou se stal státoprávní (později národní) demokrat dr. Karel Kramáŕ, místopředsedy agrárník Antonín Švehla a čs. socialista Václav Klofáč, jednatelem sociální demokrat František Soukup.

Národní výbor zř́dil svoji kancelář ve dvou místnostech Obecního domu v Praze, které mu zapůjčil Anglický klub. Kanceláŕ organizačně zajišt’ovala práci komisí výboru, kterými byly komise ústavní, hospodářská, zahraniční, finanční, menšinová, sociálně-politická a tisková. Hlavním účelem práce komisí byla příprava na převzetí moci, neboli, jak se dobově ř́kalo, na „revoluční převrat“. Vznikly zde i návrhy na první politická, hospodářská a právní opatření samostatného státu. Zároveň začala vznikat sít místních národních výborů, jimž v tu pravou chvíli měla připadnout role představitelů nové moci $\mathrm{v}$ regionech. Předpokládané převzetí moci mělo být co nejlépe organizováno, aby se předešlo zmatkům a chaosu, který mohl vyústit v násilí a rovněž zásadní sociální konflikt. Tomu chtěla česká politická reprezentace předejít. Připravené dokumenty ústavně právního charakteru nicméně odpověd’ na otázku, zda by nový československý stát měl být republikou, nedávají. Existovalo několik návrhů a i ten nejrozpracovanější Pantůčkův hovořil o prozatímní vládě „ř́íše české“ a spíše tak počítal s konstituční monarchií. ${ }^{1}$ Ostatně myšlenka na republiku nebyla (nejen) mezi českými politiky do první světové války nijak rozš́řrená a většina $\mathrm{z}$ nich si ji nedovedla ve středoevropském prostoru (podobně jako samostatný český a natož pak československý stát) představit.

Proces vzniku československého státu je poněkud komplikován také tím, že byl jako subjekt mezinárodního práva uznán Dohodovými spojenci ještě před tím, než jeho vznik ,prvním zákonem“ prohlásil Národní výbor, se projevil i v tom, že kromě Národního výboru existovala ještě jedna reprezentace státu - exilová vláda vytvořená 14. ř́jina 1918 z Československé národní rady sídlící v Paříži. A zahraniční reprezentace vedená T. G. Masarykem se k myšlence státoprávní podoby nového státu též vyjadřovala. I když byl Masaryk ochoten ještě v roce 1915 připustit, že by se mohlo jednat i o konstituční monarchii (a hledal např́klad vhodného př́slušníka britské královské rodiny), v roce 1918 již u něj a jeho spolupracovníků plně převládala orientace na republikánskou formu státu. A tzv. Washingtonská deklarace, předaná Masarykem 17. ř́ijna 1918 americké vládě a prezidentovi W. Wilsonovi, o tom hovořila jasně. Nejprve odmítla „svatokrádežné tvrzeni, že moc dynastie habsburské a hohenzollernské je původu božského...", a poté prohlásila, že „náš národ povolal Habsburky na český trůn ze své svobodné vůle a tímtéž právem je sesazuje. Prohlašujeme tímto habsburskou dynastii za nehodnou, aby vedla náš národ, a upíráme jí veškerá práva vládnout československé zemi, která, to zde nyní prohlašujeme, bude od nynějška svobodným a nezávislým lidem a národem.“

Pozůstalost A. Meissnera, za zapůjčení xerokopií děkuji dr. Petru Meissnerovi.

2 K tomu viz podrobněji KLIMEK, A. et al. (eds.): Dokumenty československé zahraniční politiky. Vznik Československa 1918. Praha: Ústav mezinárodních vztahů, 1995. 
Deklarace poté výslovně potvrdila, že Československo „,bude republikou“, která navíc zaručí základní občanská práva a svobody. ${ }^{3}$

Aby se zajistilo, že obě reprezentace - domácí a zahraniční - budou při vytváření nového československého státu postupovat společně, odjela dne 25. ř́ijna delegace Národního výboru vedená Karlem Kramářem do Ženevy, kde ve dnech 28.-31. ř́jna 1918 vedla jednání s E. Benešem jako zástupcem exilové vlády. Na těchto jednání byla mimo jiné diskutována i otázka formy budoucího státu - tj. zda bude republikou či zda existují nějaké důvody proč zachovat formu konstituční monarchie. V zásadě jediným, kdo na jednáních nepřijal republiku jako formu státu hned a bez rezervy byl Karel Kramár̆, jakkoli jeho představy o vazbách na, byt' reformované, carské Rusko byly po bolševické revoluci v troskách. Oficiální záznamy o výsledku jednání se však pro „republikánské politické zřízení“ vyslovily a Kramář tyto dokumenty podepsal. ${ }^{4}$

Události v Rakousku-Uhersku i doma však dostaly rychlý spád, a proto dne 28. října 1918 prrijala v Praze prŕitomná část předsednictva Národního výboru - Antonín Švehla, František Soukup, Jiří Stř́ibrný, Alois Rašín a Vavro Šrobár (zvaní proto též „Mužové 28. října") zákon o vzniku samostatného československého státu. Zákonu, jehož autorem byl Alois Rašín, se také říká recepční zákon, nebot' na jeho základě byl přejat do československého práva (recipován) dosavadní rakousko-uherský právní řád a více méně i dosavadní správní organizace. Nicméně právě forma státu byla podle článku I. recepčního zákona ponechána dohodě Národního výboru s exilovou reprezentací (,státní formu čs. státu určí Národní shromáždění ve srozumění s ČSNR v Paříži jako orgánové jednomyslné vůle národa“) na výše zmíněném jednání v Ženevě, o jehož výsledcích nebyly v Praze žádné informace. První čs. zákon tak republiku neprohlásil, i když se tak fakticky dělo na shromážděních na náměstích (včetně toho pražského na Václavském náměstí) a paradoxem je, že republika byla požadována již v průběhu generální stávky vyhlášené tzv. Socialistickou radou 14. ř́jjna 1918. ${ }^{5}$ A tak např́iklad Lidové noviny 29. ř́ijna 1918 na titulní stránce přetiskly provolání Národního výboru a neoznamovaly vyhlášení republiky, ale jen „samostatného československého státu“. Ostatně také zákon č. 1 hovořil o Sbírce zákonů a nařízení státu československého a recepční zákon v ní byl se změnami publikován až pod č. 11/1918 Sb.

Národní výbor, jemuž se měly podř́ídit všechny správní orgány, v sobě zahrnoval jak nejvyšší exekutivní moc, tak i moc legislativní spočívající v přijímání prvních československých zákonů a nařízení. Práci Národního výboru řídilo jeho předsednictvo,

3 Viz např. KOZÁK, J. B.: T. G. Masaryk a vznik Washingtonské deklarace vrrijnu 1918. Praha: Melantrich, 1968 s. 46 a s. 64 a násl. Viz též anglický text Declaration of independence of the Czechoslovak nation by its Provisional Government, 18 October 1918, Printed for the Czechoslovak Arts Club by the Marchbanks Press, New York 1918 a KOVTUN, G. J.: The Czechoslovak Declaration of Independence: A History of the Document. Washington D.C.: Library of Congress, 1985.

4 KLIMEK, A. et al. (eds.), c.d., dok. č. 184-186.

5 Socialistická rada byl společný orgán soc. demokratická a socialistické (národně socialistické) strany $\mathrm{v}$ rámci Národního výboru. Generální stávka byla vyhlášena proti situaci se zásobováním potravin a proti vývozu uhlí. Viz GALANDAUER, J.: O samostatný československý stát 1914-1918. Praha: Státní pedagogické nakladatelství, 1992, s. 74 a násl. O 14. říjnu 1918 jako o prvním prohlašování republiky se debatovalo i v parlamentu na 80. schůze Národního shromáždění československého v pátek dne 3. října 1919, když se diskutovalo o Benešově expozé zdůrazňujícím roli zahraničního odboje na vyhlášení republiky. Dostupný také online: www.psp.cz/eknih/1918ns/ps/stenprot/080schuz/s080001.htm [cit. 26. 1. 2018]. 
které se tak stalo de facto československou vládou, zatímco roli zákonodárného orgánu hrálo plénum Národního výboru. První dny nového státu přinesly hektickou politickou, správní, diplomatickou i normotvornou činnost budující základy nové československé státní moci.

Ačkoli v zásadě československý stát přejímal rakouské a uherské právo a správní organizaci, nejvyšši ústavní orgány pro oblast zákonodárné, výkonné a soudní moci musely být vytvořeny nově. Všechny tyto orgány československého státu vznikaly v prvních dnech po vyhlášení Československa zákonodárnou činností Národního výboru. Nejprve byly na základě návrhu F. Pantůčka zřízeny Nejvyšší správní úřady (označované tak namísto př́liš „,rakouského“ a údajně monarchistického pojmu ministerstva) nového státu, a to na základě zákona Národního výboru č. $2 / 1918 \mathrm{Sb}$. z. a n. ze dne 2. listopadu 1918. Takto byly zř́zeny nejvyšší správní úřady k „obstarávání nejvyšší správy státni“" pro resorty vnitra, národní obrany, financí, spravedlnosti, vyučování a národní osvěty, průmyslu, obchodu a živností, dopravy, veřejných prací, zemědělství, sociální péče a veřejného zdravotnictví. Velmi záhy se však československý stát vrátil k tradičnímu označování nejvyšších správních úřadů jako ministerstev a jejich „správcư “ jako ministrů. Původní soustava dvanácti nejvyšších správních úřadů byla doplňována podle aktuální potřeby správy státu, a tak např́klad již 5. listopadu 1918 bylo zř́zeno ministerstvo pro zásobování lidu a 13. listopadu 1918 přibylo ministerstvo pošt, telegrafů a telefonů. Zvláštní způsob připojení Slovenska k československému státu se promítl i do organizace vlády, nebot' 10. prosince 1918 byl přijat zákon č. 4/1918 Sb. z. a n., o mimořádných přechodných ustanoveních na Slovensku, a na jeho základě byl jmenován zvláštní ministr s plnou mocí pro Slovensko.

V tomto kontextu se začal Národní výbor připravovat na dokončení ústavního zakotvení nového československého státu. Zbývalo totiž vyřešit, na jakém základě se má vytvořit první zákonodárný stát nového státu a zda budou základní změny „převratu“ postaveny na nějaký ústavně právní základ. Na základě původní Švehlovy iniciativy se o tom diskutovalo v Národním výboru od 2. listopadu 1918. Podle autentického Švehlova vyjádření již původní ústavní komise Národního výboru před 28. říjnem pracovala na návrhu ústavy, „avšak netušili jsme, že se Rakousko tak rychle rozsype“. Zároveň připomněl, že existovalo hned několik návrhů na ústavně právní řešení, avšak průběh „převratu“ způsobil, že dosavadní návrhy byly „zahozeny“ a zvítězila představa o nutnosti „,vypracovat ústavu lepši ${ }^{\prime \prime} .{ }^{6}$

$\mathrm{Z}$ tohoto důvodu ústavní sekce Národního výboru dostala od předsednictva 8 . listopadu 1918 za úkol vypracovat zákonný podklad pro svolání Národního shromáždění, ustavení vlády a volbu prezidenta. ${ }^{7} \mathrm{Z}$ tohoto zadání již bylo zřejmé, že stát bude republikou (ostatně Kramář po návratu z Ženevy Národní výbor o výsledcích jednání s Benešem seznámil) ${ }^{8}$, zajímavé ale je, že se v instrukcích neobjevil požadavek nějakého jejího slavnostního vyhlášení či deklarace republikánské formy v úvodních ustanoveních. Hlavním požadavkem předsednictva Národního výboru totiž bylo, aby takovýto podklad byl opatřen co nejdřive. Peroutka sám hovoří v souvislosti s prípravou o spěchu

\footnotetext{
Národní archiv Praha, Fond Národní výbor, karton č. 1.

PEROUTKA, F.: Budování státu. Díl I. Praha: Nakladatelství Lidové noviny, 1991, s. 158.

Národní archiv Praha, f. Národní výbor, karton, č. 1.
} 
a dokonce o ,improvizaci“, nebot' se věřilo, že prozatímní ústava bude mít platnost ,jen několika týdnů, nejvýše měsíců, než Národní shromáždění usnese se na ústavě definitivní". 9

Referentem ústavní sekce Národního výboru, jemuž tento úkol nakonec připadl, byl sociálně demokratický politik a advokát JUDr. A. Meissner. Jakkoli je prozatímní ústava jen jedním z krokủ k ustavení československé státnosti a již výše jsme viděli, že byla považována za projev ,improvizace“, její př́prava a obsah si přesto zaslouží detailnější pozornost i ve vztahu $\mathrm{k}$ tématu této studie. $\mathrm{V}$ otázce její př́pravy se většina autorů dosud držela informací Ferdinanda Peroutky obsažených v jeho obsáhlém díle Budování státu. To samožrejmě budeme činit i my, zároveň je však možné využít i dokumentů, jež se zachovaly v archivu Meissnerovy rodiny. ${ }^{10}$ Ty umožňují Peroutkův popis událostí doplnit o vývoj vlastního navrženého textu. $V$ pozůstalosti $A$. Meissnera se dochovaly 3 návrhy a opisy prozatímní ústavy, avšak je nutno podotknout, že Meissner není jediným autorem. Aktivně se na pracích podílel i další členové ústavní komise dr. Václav Bouček, Karel Engliš a z politiků Antonín Švehla, Emil Franke a Msgre Jan Šrámek. J. Stránský se poté věnoval př́íravě souvisejícího jednacího řádu Národního shromáždění.

V Meissnerově pozůstalosti se zachovaly 3 strojopisné a 2 rukopisné návrhy prozatímní ústavy. $Z$ nich, a také ze zachovaných doprovodných materiálů, je patrné, že Meissner vycházel z výše zmíněného Pantůčkova návrhu zákona „daného prozatímní vládou rríše české“. Původně se navíc namísto prozatímní ústavy hovořilo pouze o „zákonu Národního výboru o Národním shromáždění“. Takto ještě návrhy projednávaly 9. listopadu orgány Národního výboru - předsednictvo a poté i plénum.

Termín pro dokončení prozatímní ústavy byl dán do 12 . listopadu. V této souvislosti je nutno připomenout, že základní politickou linii pro práci ústavní komise na ústavě dal 9. listopadu i předseda Národního výboru Karel Kramář, který se právě na plénu Národního výboru vyjádřil v tom smyslu, že Národní shromáždění nebude voleno, ale vytvořeno rozšsiřením pléna Národního výboru a tedy „stranami jmenováno“. A právě toto Národní shromáždění poté mělo zvolit vládu. To poté dále konkretizoval A. Švehla a dílčí podněty vznesli i K. Engliš (ohledně legislativního procesu), J. Stránský, E. Franke a J. Stř́ibrný (aby moc zákonodárné kontrolovala moc výkonnou). ${ }^{11}$ Po Englišově a zejména Meissnerově expozé na plénu Národního výboru 9. listopadu, kde kritizoval jistý diletantismus v dosavadních ústavních debatách, se právě teprve po 9. listopadu 1918 začalo hovořit o prozatímní ústavě. Ostatně následné úpravy činěné Meissnerovou rukou ve strojopisných návrzích zachovaných $\mathrm{v}$ jeho pozůstalosti pracují již s označením „zákon Národního výboru o prozatímní ústavě“.

Republikánská forma státu byla vyjádřena tím, že v čele státu měl být „státní prezident“. Poté vyškrtla ústavní komise Národního výboru slovo „státní“ a pracovala s pojmem ,prezident“, aby se teprve v poslední verzi těsně př̀d schvalováním objevil pojem „prezident republiky“ dopsaný do strojopisu Meissnerovou rukou.

Meissnerův návrh na volbu prezidenta Národním shromážděním počítal s dvoutřetinovou většinou za př́tomnosti dvou třetin poslanců. Úřad prezidenta měl trvat podle

\footnotetext{
9 PEROUTKA, F.: cit. d., s. 158.

10 Pozůstalost A. Meissnera.

11 Viz zápis o schůzi NV 9.11. Národní archiv Praha, f. Národní výbor, karton č 1.
} 
původního Meissnerova návrhu „do té doby než podle ústavy konečné hlava státu bude zvolena“. Prezidenta měla též v době jeho neprítomnosti zastupovat „vladařská rada“, což bylo poté změněno na vládu, která tím mohla pověřit svého předsedu.

V návrzích byl též zajímavý postupný vývoj rozsahu prezidentských pravomocí, v původních verzích byly totiž poměrně omezené. Státní prezident nebyl trestně odpovědný. Podle rukopisných návrhů měl zastupovat stát navenek, být nejvy̌̌ším velitelem vojska, přijímat vyslance, zastupovat stát ve styku mezinárodním, podle usnesení Národního shromáždění vypovídal válku a „předkládal mu sjednaný mír ke schválení“. Mohl též zmírňovat tresty, které byly vysloveny soudy, stejně jako právní následky trestného činu, odsouzení nebo trestu. Mohl též „naříditi, aby trestní řízení nebylo zahájeno nebo aby trestní rízení nebylo zahájeno, anebo zahájené ř́zení trestní bylo opět zastaveno“. Obsazoval též , všechna místa civilních státních zaměstnanců a soudců, jež jsou ve třídě hodnostní VI. a vyšší “. Teprve dodatečně bylo zařazeno suspenzivní veto, a to jako právo prezidenta vrátit zákon usnesený Národním shromážděním ve lhůtě 3 dnů k novému projednání. Setrvalo-li Národní shromáždění na svém původním návrhu, měl být zákon vyhlášen. $\mathrm{K}$ vládním úkonům, které vykonával prezident, byl vyžadován souhlas „vladařské rady“ a spolupodpis jejího odpovědného člena.

O změně pojmu „vladařská rada“ (což př́liš neevokovalo republikánskou formu státu) na vládu již byla řeč, zajímavé byl i vývoj počtu navrhovaných členů z původně 12 na konečných 17 členů, aby ve vládě byla skutečně zastoupena „všenárodní koalice“ a také zástupci exilové prozatímní vlády. Dodatečně byla do návrhu ústavy dopsána i důležitá poznámka o vyhlašování rozsudků jménem republiky, když podle původní verze $\$ 13$ se „rozsudky a nálezy soudü“ vyhlašovaly ,jménem svrchovanosti lidu“.

Konečná redakce návrhu prozatímní ústavy byla dne 12. listopadu 1918 projednána předsednictvem Národního výboru. Dne 13. listopadu jej na schůzi s určitými připomínkami a po místy bouřlivé debatě schválilo v Grégrově sále Obecního domu plénum Národního výboru. Debatu řídil A. Švehla, který hovořil o Národním shromáždění jako o „konstituantě“ a předvídal tak hlavní úkol, který před Prozatímním Národním shromážděním ležel. Debatu se snažil urychlit i poukazováním na to, že se jedná o „provizorium“, které bude brzy posuzovat ústavní výbor Národního shromáždění pověřený př́pravou ústavy „definitivni“. K. Engliš jako ,jurista“ hodlal předložit své minoritní vótum, že i když byl členem užší komise pro prrípravu textu prozatímní ústavy, nesouhlasil se způsobem rozšíření Národního výboru na Národní shromáždění. Za jedině správný způsob pokládal jmenovité uvedení všech jeho poslanců. $\mathrm{K}$ tomu se vyjádřil Švehla v tom smyslu, že návrh př́slušného paragrafu definitivně prosadil on a prosil, aby i dr. Meissner byl v této záležitosti „z obliga“. Další významný pozměňovací návrh přednesl opět Engliš, když požadoval, aby zákonodárnou pravomoc Prozatímního Národního shromáždění byla omezena jen na věci „pilné a neodkladné“ a to proto, že parlament nevznikl volbou. Plná zákonodárná pravomoc tak měla být svěřena teprve parlamentu zvolenému na základě „, všeobecného, prrímého, tajného práva hlasovacího“, aby „nám nikdo nemohl ř́ci, že jsme si usurpovali moc“. Jeho návrh však byl velkou většinou zamítnut.

Předseda Národního výboru K. Kramáŕ zase prosazoval volbu prezidenta kvalifikovanou většinou dvou třetin všech poslanců. Dr. Meissner nakonec uhájil svůj návrh na 
nutnost pro volbu prezidenta dosáhnout prítomnosti dvou třetin poslanců a většiny dvou třetin jen př́tomných poslanců, $s$ odůvodněním, že by jedna třetina poslanců mohla činit při volbě obstrukce a Kramár̆ tak vzal svůj pozměňovací návrh zpět. Sociálně demokratický politik K. Modráček se poté snažil ještě omezit postavení prezidenta a zejména jeho imunitu danou $v \S 9$, podle nějž nebylo možné prezidenta vůbec trestně stíhat. Modráček hodlal imunitu hlavy státu postavit na roveň s imunitou poslaneckou. Zvolené řešení obhajoval dr. Bouček a poukazoval přitom i na uvažovanou osobu prezidenta profesora Masaryka, v něhož má neomezenou důvěru. Doslova uvedl, že nezradil-li nás dosud, nezradí nás ani jako prezident.

Debatovalo se ještě o počtu členů vlády (jejich velký počet kritizovala Socialistická rada), o počtu členů Prozatímního Národního shromáždění za Slovensko i o absenci ustanovení o občanských právech. ${ }^{12}$ Poté, co byl znovu přečten a schválen celý text návrhu prozatímní ústavy, došlo ještě ke krátké diskuzi o platech ministrů, přičemž bylo rozhodnuto ponechat tuto otázku zvláštnímu zákonu. Schválený text byl pod č. 37/1918 Sb. z. a n. publikován jako prozatímní ústava. Prozatímní ústava nabyla účinnosti dnem vyhlášení, tj. 14. listopadu 1918.

I když jsme viděli, že republikánská forma vlády z prozatímní ústavy vyplývala, je důležité ještě připomenout, jak byla prozatímní ústava naplněna a i republika se stala dokonaným skutkem. Na první schůzi PNS dne 14. listopadu přečetl Karel Kramář, stále jako úřadující předseda Národního výboru a také jako předsedající schůze i toto prohlášení republiky: „Všecka pouta, která nás vázala k dynastii Habsbursko-Lotrinské, jsou přervána (Výborně! Poslanci povstávají, hlučný potlesk.) Konec jest smlouvám z r. 1526 i pragmatické sankci (Výborně, potlesk) Dynastie habsbursko-lotrinská ztratila všechna práva na trůn český (Tak jest! Výborně! Potlesk.) A my svobodni a volni prohlašujeme, že náš stát československý jest svobodnou československou republikou. (Výborně! Sláva!) Hlučný potlesk.)“ 13 Poté byl tento akt potvrzen zvolením T. G. Masaryka „prvním presidentem Československé republiky.“ Podle stenografického zápisu stalo se tak jednomyslně voláním Výborně! Sláva! Potlesk a následným Kramářovým konstatováním: „Prohlašuji tedy professora dra. Tomáše G. Masaryka jednohlasně zvoleným presidentem Československé republiky“. Poté došlo k volbě orgánů Národního shromáždění, které následně podle ústavy slavnostně a jednomyslně zvolilo první čs. vládu v čele s ministerským předsedou Karlem Kramáŕem. Československo se tak skutečně stalo 14. listopadu 1918 republikou.

prof. JUDr. Jan Kuklík, DrSc.

Právnická fakulta Univerzity Karlovy

kuklik@prf.cuni.cz

12 Blíže viz KUKLÍK, J.: Příprava a přijetí prozatímní ústavy. In: Československá ústava 90 let poté. Praha: IVK, 2015, část 9.

13 Dostupný také online: http://www.psp.cz/eknih/1918ns/ps/stenprot/001schuz/s001001.htm [cit. 26. 1. 2018]. 